\title{
Innovative Approach to the Analysis of Enterprise's Competitive Capacity
}

\author{
Valery I. Roldugin ${ }^{1, *}$, Ravshan Kayumov ${ }^{2}$ \\ ${ }^{1}$ Department of Entrepreneurial Activity, Baltic International Academy, Latvia \\ ${ }^{2}$ Department of Finance and Credit, Tax Academy of the Republic of Uzbekistan, Uzbekistan
}

Copyright $\mathrm{C} 2018$ by authors, all rights reserved. Authors agree that this article remains permanently open access under the terms of the Creative Commons Attribution License 4.0 International License

\begin{abstract}
Nowadays it is recognized that entrepreneurship and innovation lie at the heart of economic growth. In the article the authors research an innovative approach to the analysis activity of the Uzbekistan enterprises with international companies. The purpose of this article consists in a research of theoretical problems which are connected with competitiveness of the international organizations. The formation and the development of funding infrastructure to support international companies in the early stages is a complex process that depends on a number of factors, requiring the special approach to the analysis of enterprise's financial performance. Additionally, it presumes high business activity to creating new businesses, some of which succeed and some fail trying to overcome the uncertainties of the enterprise risks and profitableness. In progress of the thesis, different scientific methods of research have been used, including: system analysis, formalization and modeling.
\end{abstract}

Keywords Entrepreneurship, Financial Stability, Essential Indicator, Logistics, Management

JEL classification $G 32$, G39

\section{Introduction}

Entrepreneurship, innovation and competitiveness issues are of particular importance for the so-called "catch-up countries," which includes Uzbekistan as well. The success of the reforms in our country is largely determined by the development pace of basic industries of the economy. Achieving this goal requires radical restructuring of economic relations in these sectors of the economy, which in turn requires modernization of their production capacity.

There exist a lot of definitions and different ways of competitive capacity estimation. Competitive capacity of a company this is an ability to use its strong potentials and concentrate on efforts in the field of goods or services where it can take the leading position in the inner and external markets.

Company "Euroimpex trans mchj" provides a full complex of international cargo shipping, cargo forwarding services and customs warehousing. Company is an international company where exist main factors defining the competitive capacity of the company. The following include: firm strategy, presence of material, working and financial resources, and innovative potential, part of the market and management efficacy. Estimating competitive capacity of Euroimpex trans mchj is important to take into account main factors of its products competitiveness, competitiveness of a company and country where the company is based [8].

Table 1. Competitive capacity main components of International companies

\begin{tabular}{|ll|ll|}
\hline $\begin{array}{l}\text { Resources and possibilities of a } \\
\text { company }\end{array}$ & \multicolumn{2}{|c|}{$\begin{array}{l}\text { Competitive conditions of } \\
\text { branch }\end{array}$} \\
\hline$\bullet$ & Financial resources & $\bullet$ & Innovation \\
- & Material actives & $\bullet$ & Access to raw materials \\
- & Technology & $\bullet$ & Science research and \\
- & Reputation, clients & & works out \\
- & Optimization of expenses & $\bullet$ & Access to market \\
- & Functional possibilities & $\bullet$ & Low expenses \\
- & Management. & $\bullet$ & Quality \\
& & $\bullet$ & Monopoly \\
& $\bullet$ & Qualified personnel \\
& $\bullet$ & - Part of market. \\
\hline
\end{tabular}

To raise competitive capacity of International company, in our case Euroimpex trans mchj, there is the need of production and realization expenses analysis and estimation of correlation expenses. To attain optimization of production expenses necessarily to use intercompany account among its subdivisions which are appear as profit centers. With requests to intercompany administration system there is a coherency of reaching effective production, optimization of expenses and effectiveness in market activity [12].

Above-named positions are called to define firm's potential possibilities and actions which the firm needs to take to provide it with competitive capacity in the concrete market. Euroimpex trans mchj uses de-centralized system of administration leaving economical independency to its 
subdivisions. The determined feature of companies like this one is legible borders disappearance in between main functional fields such as marketing, planning and controlling. The base of this system is strategic administration. The realization of administration in International company should recline on single accounting and control system with the use of newest programming and software securing.

Another factor of International companies' success, which is present in Euroimpex trans mchj, is the creation of information system which secures the acceptation of effective and auspicious decisions. It can be reached by result of using informational and communicative technologies which give possibility of fast receiving and exchanging information in all companies' subdivisions.

Special requirements are necessarily to International companies' managers. The most important factor is communicability and the ability to discount cultural personnel specifics. The important meaning has the ability of manager to "tie up" global companies' purposes with its national interests, the cultural integration ability, knowledge of few languages, education ability and mobility [13].

Managers-professionals must unite in itself skills of inquire in global strategy questions and corporate politics, innovations, guidance of "human resources" with the deep knowledge in concrete fields of science. All of these are necessary to keep the image of all the employees of enterprise and each of employees, the unity of activity of subdivision, enthusiasm and innovators initiative.

Summarizing all above, can be mentioned that in XXI century market prospects will define large International companies which are characterized by high innovation activity and could use all progress factors to raise its competitive capacity.

Competition is the second term which is needed to be defined. Competition is the act of striving against another force for purpose of achieving dominance or attaining a reward or goal, or out of a biological imperative such as survival. Competition is a term widely used in several fields, including biochemistry, ecology, economics, business, politics and sports. Competition may be between two or more forces, life forms, agents, systems, individuals, or groups, depending on the context in which the term is used.

Competition may yield various results of the participants, including both intrinsic and extrinsic rewards. Some, such as survival advantages, including favorable territory, are intrinsic biological factors that occur as a result of ecological competition between organisms. Others, such as business dominance and political power, involve competition between humans. In addition, extrinsic symbols, such as trophies, plaques, ribbons, prizes, or laudations, may be given to the winner(s). Such symbolic rewards are commonly used wherever the rewards inherent in the competition are primarily intrinsic, such as at human sporting and academic competitions. In general, the rewards range widely but usually help reinforce the advantage that one participant has over the other participant(s).

It should also be noted that business and economic competition in most countries is often limited or restricted. Competition often is subject to legal restrictions, which usually provide for fair and equal business competition [9]. Such laws may include the banning of monopolies and price gouging. Depending on the respective economic policy, the pure competition is to a greater or lesser extent regulated by competition policy and competition law. Competition between countries is quite subtle to detect, but id quite evident in the World economy, where countries like the US, Japan, the European Union, and the East Asian Tigers each try to outdo the other in the quest for economic supremacy in the global market, harkening to the concept of Kiasuism [10]. Such competition is evident by the policies undertaken by these countries to educate the future workforce. For example, East Asian economies like Singapore, Japan and South Korea tend to emphasize education by allocating a large portion of the budget to this sector, and by implementing programmers such as gifted education, which some detractors criticize as indicative of academic elitism [11].

\section{Approaches to the Analysis of Enterprise's Competitive Capacity}

Nowadays it is well recognized that entrepreneurship and innovation lie at the heart of economic growth and create new jobs. Addressing the environmental and social issues, innovation contributes to creating conditions for sustainable development. Additionally, it presumes high business activity to creating new businesses, some of which succeed and some fail trying to overcome the uncertainties of the market and technology. Due to this uncertainty and uneven distribution of the information among market participants it is difficult for traditional financial institutions to support specific innovative enterprise as they also consider the risks and profitability. Therefore, in the most uncertain stages of its development, innovative enterprises depend on private investors or specialized intermediaries. When there is an "alternative" source of financing, innovation systems function effectively, creating and increasing the wealth and thereby ensuring job creation and economic growth.

However, the formation and the development of funding infrastructure to support innovative companies in the early stages is a complex process that depends on a number of factors and conditions and it requires efficient capital allocation and circulation.

Modernization of the economy should foster production technologies and products come in tune with the standards of developed countries. For the modernization sufficient 
investments are needed to update the fixed assets and maintain sustainable economic development. In accordance with the Uzbekistan's current strategic economic development program an active investment policy should be carried out aimed at further structural reforms, diversification of industries and sectors of the economy, deepening the process of modernization, technical and technological renovation of production, as well as the development of transport, engineering, communications and social infrastructure. Effectiveness of these activities is largely determined by the degree of using innovative technologies. At the same time, innovation should be applied not only in the production, technology, marketing, but also in the financial condition appraisal of the enterprises too.

Financial condition is an essential indicator of company's economic activities and determines its competitiveness and to what extent the company's economic interests are guaranteed in terms of finance and production. Financial condition is characterized by the availability of funds necessary for the normal functioning of the enterprise, appropriate allocation and its effective use. A fundamental aspect of financial analysis is the provision timely assessment of company's actual condition and efficiency of economic activity for its management and stakeholders, which is the important element of the control system.

International practice provides a wide range of financial indicators, therefore one of the problematic aspect of financial analysis is to select a certain number of key parameters, the most informative, which gives a fairly objective and accurate picture of the financial condition of the company in: profit and loss, changes in the structure of assets, liabilities, costs and payments with debtors and creditors. In the view that all countries use accounting standards similar to international, the financial statements reveal the enterprise's financial condition are practically identical. Accordingly, the analysis methods and performance indicators are also identical.

In particular, the authors of the popular in the US textbook "Finance" write: "In analyzing the financial performance of the company based on its financial reports by using a number of special ratios you can compare it with the performance of different companies or its performance for different periods. Using these ratios, it is possible to analyze the five main aspects of the company's effectiveness: profitability, asset turnover, financial leverage, liquidity and market value [1]. Braley R. and Myers S. give the same grouping of these indicators, but only call them types of financial ratios [5]. The authors of the textbook "Fundamentals of Management" call groups of ratios [3].

In textbooks published in the neighboring countries, the majority of authors distinguish four groups of ratios. The fifth group of the ratio related to issues of market valuation activity covered in textbooks on corporate finance [4].
Study of methodological and academic literature has shown that some authors give their recommendations on normative values of some parameters. This applies mainly to liquidity and equity autonomy. The standard value of the absolute liquidity ratio is recommended to set at $0.2[4,7]$; $0.2-0.25[6] ; 0.3$ [2]. The standard value of quick ratio according to this author's opinion should be $0.7 ; 0.7-0.8$; $0.8 ; 0.8-1 ; 1$. Regulatory level of current liquidity is proposed within the range of $2 ; 2-3$.

At the same time, the authors question the correctness of the establishment of such normative values of these parameters. In particular, Lobanova E., Limitovsky M. refer to the following rule: "The rule of thumb: the current ratio should be at least 2 , and acid - not less than 1 . This rule is often declared, but is essentially useless "[2]. But then they write: "quick ratio is more consistent with the interests of the company, revealing its ability to pay timely commitments. Standard level of this ratio of 1: 1, i.e., unit, the maximum permissible level of current liquidity "[2].

We would like to draw attention to the following circumstance. The value 1 of the current ratio means current assets and current liabilities are equal and indicate enterprise lacks of working capital. The critical situation begins when the company begins to lose its own working capital. Its absence means insolvency.

In addition, the accuracy of setting up regulatory liquidity ratios is doubtful. The level of absolute liquidity 0.2 indicates that the company has available funds to cover a fifth of current liabilities. Let us assume that the bulk of the current liabilities are short-term loan obtained for a period of ten months, and it must be repaid at the end of the loan term. Then, availability of funds in the first nine months shows diversion of economic turnover, as in these months no significant mandatory payment is planned. And the availability of funds in the tenth month of credit is not enough to repay the loan.

On the other hand, the normative values of the absolute liquidity ratio and quick ratio $0.2-0.3,0.8$ - 1 determine that the absolute amount of the receivables should exceed the amount of cash on the balance sheet 3-4 times. But how this relationship justified is not clear.

Suggested levels of standards for the equity ratio are also under doubt. Pribytkova G. offers this ratio to be at 0.5 . [4] Similar opinion is shared by the authors of the textbook edited by Shokhina E. [7]. According to the authors of the textbook edited by Stoyanova E., this figure should be not less than $60 \%$ [6]. In theory, the formation of the company's assets, equity should cover the constant need for resources and working capital need to be covered by borrowing. But in sectors of seasonal production basic need is of temporary nature. Therefore, such a ratio of equity to current liabilities is groundless.

For the correct analysis firstly it is necessary to determine what parameter groups are the most important. In practice these are liquidity and solvency ratios (capital autonomy or financial independence). But the value of 
liquidity ratios depends on the frequency of sales, namely, determined by the rate of assets turnover, mainly current. Particularly, if the business has daily sales, it is unlikely to have liquidity problems. And if the sale of products is carried out periodically (say once a month), the entity shall have absolutely liquid assets with appropriate maturity to cover current liabilities. Therefore, the shorter the sales interval, the less you need to keep funds in the account. This is mainly important if we consider that assets must be in circulation instead of lying idle. This approach to assess the absolute liquidity ratio allows you to accurately determine not upper and lower bounds, but its exact value for a specific period.

With this procedure in assessing the liquidity, we need to approach quick liquidity ratio in a completely different way. It shows the level of financial competency of company's financiers. We will explain this with the above mentioned example, companies with monthly sales (this is a typical example for the construction companies that receive payments from customer on a monthly basis after issuing act of completion). Suppose the company in the coming month is expecting to repay current debts in the amount of 100,000 soums, accordingly, it should have appropriate funds in its account. But if the average receivables turnover is 20 days, and expected cash inflow is 60,000 soums, it will be more precise to keep only 40 thousand in the accounts, and the rest put into circulation. I would like to note that only skilled financial managers can handle such liquidity policy. If the receivable is not received on time, to raise funds for a short period of time for them is not difficult.

From the above it can be concluded that a unified standard value for the coefficients of absolute and quick ratios do not exist. With regard to the current ratio, its size should be greater than one. The exact value of this coefficient is calculated from the equation: value of current assets equals the sum of current liabilities and net working capital. Therefore, the larger is the net working capital (capital), the higher is the value of this coefficient.

Solvency ratio or financial stability is calculated as the ratio of equity to debt. But borrowing consists of two different parts, long-term and short term liabilities. When analyzing the financial independence of the company, it is important to assess the validity of attracting long-term debt sources as company's capital, i.e., to evaluate the effect of financial leverage. The law of economies of scale suggests: the larger the company, the cheaper the cost of production. Therefore, if the cost of long-term debt is below the level of return on company's capital, its acquisition is justified and even beneficial, because it increases the rate of return on equity. The greater the difference between the return on equity and the cost of borrowed funds, the more profitable is its presence. Therefore, setting ratio norms in this case is inappropriate or even meaningless.

Current liabilities of the enterprise consist of short-term loans and payables. Given the fact that the funds of creditors is the cheapest, but rather a rate free source of attracting resources, from the company's perspective, its growth is beneficial. Constraints of such growth are settlement and payment discipline in the country and the risk of deferred liability that cause sanctions.

As for short-term loans, their volume should not be determined by any regulatory levels to equity. They must be formed based on their economic purpose: short-term loans are raised to meet temporary financial needs. The constant need should be covered by own working capital of the enterprise. If we consider that the level of solvency for current obligations of the enterprise depends on the level of profitability of sales and turnover rate of its assets, the company with a high return on sales will not experience difficulty in paying debts (enough profit) and high turnover (more frequent) provide constant cash inflows for the timely and full payments.

From the above it can be concluded that the main parameters determining the effectiveness of the company are the return on equity (assets), return on sales and asset turnover. Their value depends on the coefficients of liquidity and solvency, which would be correct to call characterizing the activity of the enterprise. Therefore, in order to ensure efficient management of financial condition of the company, it is more logical to assess and establish normative values for the coefficients of profitability and turnover. But here the question arises - how to compare these coefficients. Here are summarized the most common in the literature opinion.

It's stated that the financial ratios illustrate the financial proportion between the different parts of the statement. The advantages of financial ratios are easiness in calculation and elimination of the inflation effect, which is especially important in the long term analysis. The common sense of the method is, firstly, in the calculation of the corresponding index and, secondly, a comparison of this index with a benchmark, such as conventional standard parameters; industry averages; similar parameters in previous years; indicators of companies competitors, (compared) enterprises; any other parameters of the analyzed company or with established norms.

At the same time, we disclose the disadvantages of this method. In particular, if the level of actual financial ratios is worse than that of comparison, it indicates to the weak points in the enterprise, and they need further analysis. However, further analysis may not confirm the provisional negative evaluation due to an increase of any factor. Thus, in some cases, one or the other coefficient does not meet the generally accepted standard rate due to specific conditions and characteristics of the business policy of an individual enterprise. In addition, it's not always reasonable to compare with the average industry coefficients, as for example many businesses follow diversification policy. Financial ratios do not capture differences in accounting methods; do not reflect the quality of the components. Finally, they are of static character. 
All these arguments are valid, but they do not reveal the main drawback used in the practice of financial performance evaluation. The current practice of assessing the financial condition allows us to estimate only the current activities of the company, but it does not aim at achieving the goals. By the goals should be understood the payback of the initial investment in the enterprise and receive an annual profit size expected by the investment project. This approach to the analysis of financial condition has several advantages. First, we consider the shareholders' interests, for whom it is important to recover their investment and get the promised benefits and not how the company performs compared to previous periods or with other companies.

Second, financial statements analysis acquires complete sense: to assess current performance in order to achieve the final result. If we look at every company - as an investment project (or set of projects), the final result is achieved at the end of the project life cycle.

\section{Possibilities of Solving Problem in Transport Area}

One of the most common theoretical problems in logistics adopted the so called "transportation problem", which helps to formalize one of the areas of production logistics "Transportation area". Transportation problem is formulated as follows [14].

There are:

m suppliers (points of departure), which accumulated large reserves of some homogeneous goods;

ai - Maximum possible supplies, where $\mathrm{i}=1,2, \ldots, \mathrm{m}$;

$\mathrm{n}$ destinations of submitted applications respectively for goods, i.e. - the number of consumers using products;

bj - volume of consumers where $\mathrm{j}=1,2, \ldots, \mathrm{n}$;

Cij - transportation cost per unit of output from the $\mathrm{i}$-th supplier to the $\mathrm{j}$-th consumer is known to all as $\mathrm{i}=1,2, \ldots, \mathrm{m}$ and $\mathrm{j}=1,2, \ldots, \mathrm{n}$.

Necessary to determine:

Xij - traffic volumes (Xij) for each supplier to each consumer to the total cost of transportation should be minimal and the needs of all customers must be satisfied (unless the total potential supply covers the overall requirements, i.e., There is no shortage of goods).

"Transportation problem" is solved using mathematical methods, as a rule with the help of a linear programming relating to the theory, "Operations Research" and applies to most practical optimization problems, the transport of goods (goods, passengers, etc.) Using models of the transportation problem "is easy to find the minimum distance of transportation, the minimum time and minimal costs for transportation of goods in the transport network. A mathematical model of the problem looks as follows:

$$
\sum_{i=1}^{m} \sum_{j=1}^{n} \boldsymbol{C} \boldsymbol{i j} \boldsymbol{X} \boldsymbol{i j} \rightarrow \min ;
$$

$$
\begin{gathered}
\sum_{j=1}^{n} \boldsymbol{X} \boldsymbol{i} \boldsymbol{j} \leq \mathrm{ai}, \mathrm{i}=1,2, \ldots, \mathrm{m} ; \\
\sum_{\boldsymbol{i}=\mathbf{1}}^{n m} \boldsymbol{X} \boldsymbol{i} \boldsymbol{j} \geq \mathrm{bi}, \mathrm{j}=1,2, \ldots, \mathrm{n} ; \\
\mathrm{Xij} \geq 0, \mathrm{i}=1,2, \ldots, \mathrm{mi}, \mathrm{j}=1,2, \ldots, \mathrm{n} .
\end{gathered}
$$

Obviously, this problem can be solved by linear programming with $m, n$ variables and $m+n$ indirect constraints.

In theory, developed a number of classical methods of solving transport problems, such as:

1) Method of the northwest corner (with the introduction of fictitious supplier);

2) Method of the northwest corner (with the introduction of a fictitious consumers);

3) Method of a minimal element (with the introduction of fictitious supplier);

4) Method of a minimal element (with the introduction of fictitious consumer);

5) The method of Vogel;

6) Knapsack problem;

7) Assignment problem;

8) The problem of 4 color (4 color method) and etc.

North West corner method (NWC with the introduction of a fictitious supplier and customer) - If considered that $\mathrm{Ai}$ is supplier and the $\mathrm{Bj}$ is the consumer than transportation plan shall start with the transport supplier reserves A1. It will be at the expense of its stock as possible to satisfy customer orders first B1, then B2 ... Bn and soon. Thus, will fill the table will be filled, starting with cell $(1,1)$, and move right along the line as long as the remainder of stock supplier A1 will not be less than the order of another customer of as soon as it will finish. To carry out this order using the remains of the stock the first supplier, adds the missing part of the stock supplier A2 that is moved to the next row of a table by column, corresponding to the specified user. Further, similarly distributes supplies of supplier A2, then A3... Am and etc. [16].

The method northwest corner is simple to implement, but it is difficult to hope that it will cost an initial plan, since the distribution of transportation cost it did not take into account.

Lowest cost entry method - this is the other classic method of solving the transportation problem, this method also called as the method minimum element. Its essence lies in minimizing the adverse redistribution of goods between consumers.

First step that needs to be done is choosing the lowest cost transportation from the table of values that corresponds to it, than satisfy its needs.

Next step is to check on-line supplier's rows and columns of consumers for the presence of a column, whose needs are completely satisfied. These columns and rows are not considered. If not all consumers are satisfied and not all suppliers have spent commodities, return to step 1 , otherwise the problem is solved.

In the lowest cost entry method, the lowest cost 
transportation position should be considered and move to up to the next higher cost position. Than at the end from the facts of the table may be calculated the transportation cost.

Vogel's approximation method - First of all needed to write the difference of minimum cost and next to minimum cost against each row in the penalty column (This difference is known as penalty). The next step that needs to be done is to write the difference of minimum cost and next to minimum cost against each column in the penalty row.

In determining the basic plan of the transportation problem by approximating Vogel at each liberation, all columns and all rows have got the difference between the two written in their minimum rates. These differences are written in a specially designated row and column in the table of the problem. Among these differences are choosing the maximum. In the row (or column), which corresponds to this difference, determine the minimum tariff. Cage in which he recorded, fill in this iteration. If the minimum rate is the same for a few cells of the row (column), then choose to fill the cell, which is located in the column (row), corresponding to the largest difference between the two minimum rates that are in this column (row).

Knapsack problem (backpack) - is a problem in combinatorial optimization. Given a set of items, each with a weight and a value, determine the number of each item to include in a collection so that the total weight is less than or equal to a given limit and the total value is as large as possible. It derives its name from the problem faced by someone who is constrained by a fixed-size knapsack and must fill it with the most useful items. The problem often arises in resource allocation with financial constraints. A similar problem also appears in combinatory, complexity theory, cryptography and applied mathematics.

The decision problem form of the knapsack problem is the question "can a value of at least $\mathrm{V}$ be achieved without exceeding the weight W"?

Necessary to define, in the following, have $\mathrm{n}$ kinds of items, 1 through n. Each kind of item it has a value vi and a weight wi. It is usually assumed that all values and weights are non-negative. To simplify the representation, it can also be assumed that the items are listed in increasing order of weight.

The maximum weight that can carry in the bag is $\mathrm{W}$. The most common formulation of the problem is the $0-1$ knapsack problem, which restricts the number xi of copies of each kind of item to zero or one. Mathematically the 0-1 knapsack problem can be formulated as:

$$
\begin{gathered}
\max \sum_{i=1}^{n} v_{i} x_{i} \leq W \text { subject to: } \sum_{i=1}^{n} w_{i} x_{i} \leq W ; \\
x_{i} \in\{0,1\}
\end{gathered}
$$

The bounded knapsack problem restricts the number $\mathrm{xi}$ of copies of each kind of item to a maximum integer value ci. Mathematically the bounded knapsack problem can be formulated as:

$$
\begin{gathered}
\max \sum_{i=1}^{n} v_{i} x_{i} \leq W \text { subject to: } \sum_{i=1}^{n} w_{i} x_{i} \leq W \\
x_{i} \in\left\{0,1 \ldots c_{i}\right\}
\end{gathered}
$$

The unbounded knapsack problem places no upper bound on the number of copies of each kind of item [15].

Assignment problem - kind of linear programming problem with which addressed questions like "how to allocate workers to machines", so that the total output was the highest or salary costs the least (since for every combination of "worker - machine" characterized his own productivity), how best to allocate carriages of aircraft, how to assign people to various position (hence the name of the task), etc. Mathematically, such problems a special case of distribution problems with the property where the amount of required to complete each of the resources are equal to unity, $a j=1, b j=1$ and all $x i j=1$, if a worker $i$ assigned to job $\mathrm{j}$, or 0 other cases. In other words, to perform the assignment each operation must consumes only one kind of resource, and each resource can be used on one job indivisible resources are indivisible between each other.

The four color problem - K. Appel and W. Haken proved in 1976 that with the help of four colors or less can be painted any map. This was the first major mathematical theorem, which required computer to prove. Despite the subsequent simplification of the proof is almost impossible to check without using a PC. Therefore, some mathematicians reacted to this proof with suspicion. Not only because of computer use, but also some description of the algorithm of first proofs were subsequently more compact algorithms than usual.

Distribution function of logistics is carried out by performing six conditions: the weight, quality, quantity, time, cost, and destination. This tells that in dealing with the management of material flow and related information flow from entering the system until the final sale. If considered the problem from the stand point of the criterion of logistics system "just in time", can be said with confidence that the company focuses on meeting the needs of the consumer, it means take into account its requests, a number of special conditions, availability of products on the market at pre-determined cost and service parameters. Solving transportation problems, the theoretical and methodological advances in this field must be used. However, it is important to apply not only achievements, but also to develop its transport strategy and identify its main principles.

\section{Conclusions}

We have developed and proposed a new framework for the analysis of companies' financial condition, which involves comparing the following indicators: actual data for the previous year, norms for the current year, the actual data for the current year, i.e. performance norms 
introduced additionally. In this case, innovation is not in the performance indicators, but the procedure in their calculation. Using normative indicators allows better manage the financial condition of the company. In addition, for the analysis proposed to use balances of assets and liabilities as of the balance sheet date, and their mean values calculated by the average method.

Fundamentally new in the developed guidelines is the procedure for calculating financial performance standards of the enterprise. To calculate the normative values of the basic indicators for assessing the financial condition of enterprises is used interconnection of these parameters. Such interconnection, if given values of one indicator, allows you to calculate the values of others. As specified indicator is proposed to use profitability of assets (total capital), as this indicator is the main purpose to establish the enterprise. The minimum value of this ratio should correspond to the index rate of profit in the enterprise project (feasibility study or business plan). Based on this index we determine normative values for return on sales and asset turnover, in turn, set normative values for liquidity and solvency coefficients.

The basis of the logistic model should be based on problems of the transport process, which would be included in this model is a realistic assumption. An important area of research is to develop analytical results for the distribution of the routing of vehicles, the study of trade-offs between stocks of resources, their transportation and placement. All these measures are intended to reduce the amount of transportation costs and deliver cargo on time

\section{REFERENCES}

[1] Bodi Z., Merton R. Finances: Trans. with Engl: Ouch. pos. M.: Publishing House "Williams", 2008, 592 p

[2] Lobanova E., Limitovsky M. Finance Manager - M.: Publishing LLC Consulting Company "Deka", 2000, 400 p.
[3] Meskon M., Albert M., Hedouri F. Fundamentals of Management/ Fundamentals of Management: Trans. With angl. - AM: Business, 1999, 800 p.

[4] Pribytkova G. Financial Management: Didactic material "Financial management in the diagrams, drawings, calculations". - Orenburg: SEI OSU, 2003, 92 p.

[5] Richard Braley, Stewart Myers. Principles of Corporate Finance: Trans. from English. - M.: ZAO "Olympus Business", 1997, 1120 p.

[6] Financial Managemen: Theory and Practice: / Textbook / Ed. E. Stoyanova. - 4th ed., Rev. and add. - M.: Publishing House of the "Perspective", 1999, 656 p.

[7] Financial Management: Textbook/ Ed. prof. E. Shokhin. M .: ID FBK-PRESS, 2002, 408 p.

[8] Дженстен Пер, Дэвид Хасси. Анализ сильных и слабых сторон компании. Определение стратегических возможностей. Издание «Дом Вильямс» Москва, Санкт - Петербург, Киев, 2004, 364 с.

[9] Кирцнер М. Израэл. Конкуренция и предпринимательство. Издание "Юнити-Дана", 2001, $240 \mathrm{c}$.

[10] Круглов В.В. Конкуренция. Учебное пособие. Издание "Проспект", ТК Велби. 2004, 80c.

[11] Левита Р.Я. История экономических учений. Учебное пособие. Москва, Инфра-М, 2002, 224 с.

[12] Мескон М.Х., М. Альберт, Ф. Хедоури. Основы менеджмента. 3-е издание. Перевод с английского. Издание «Дело», Москва, 1992, 701 с.

[13] Миклтуэйт Джон, Адриан Вулдридж. Магия менеджмента. Издание "Транзиткнига", Москва, 2004, $414 \mathrm{c}$.

[14] Кузьбожев Э.Н. Логистика. Уч. пособие. 3-е издание. М.: "КНОРУC", 2006. - C. 224

[15] Wikipedia the free online encyclopedia. Article about the classical "Knapsack problem" [Electronic resource] //http://en.wikipedia.org/wiki/Knapsack_problem.

[16] Neopolitan R., Naimipur K. Foundations of algorithms. 4th edition. 2004, 490 p. 